\title{
Whatever Happened to Home Movies? Self- representation from Family Archives to Online Algorithms
}

Lauren S. Berliner

DOI:10.15664/fcj.v19i0.2381

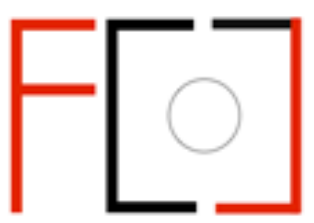

Frames Cinema Journal ISSN 2053-8812

Issue 19 (March 2022)

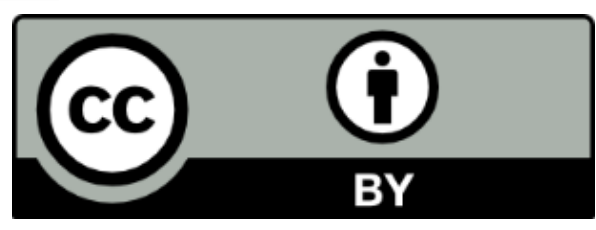




\section{Whatever Happened to Home Movies? Self-representation from Family Archives to Online}

\section{Algorithms}

Lauren S. Berliner

"Welcome to the exercise show!" a boy's voice announces, his palm covering the phone camera lens. "Today you'll be seeing our coaches...let's start!" He lowers his hand to reveal two white, healthy-looking six-year-olds in school clothes. They look at each other and giggle. "Ten jumping jacks!" says the off-camera voice. The kids count together as they bounce up and down in syncopation, arms flailing. "Five push-ups!" The children move to the floor, moving to an exercise that resembles frog jumps. When they have finished the set, they turn towards each other, grinning widely, pleased with their accomplishment.

This video of the younger children at a family gathering was taken on my sister's phone by her elder child. None of the adults in the home were aware of the recording until later that evening, when she discovered it on her phone. From there it was sent to me and other relatives. I then forwarded it to a friend in Barbados, who participates in an online fitness group with her friends, a group of middle-aged Black women of the African diaspora, spread out across the globe. She then passed the video on to them. A minute's worth of living room child's play had made it to several continents in less than a day, moving across geographies, generations, cultures, and racial identities. 
Frames Cinema Journal, Issue 19 (March 2022)

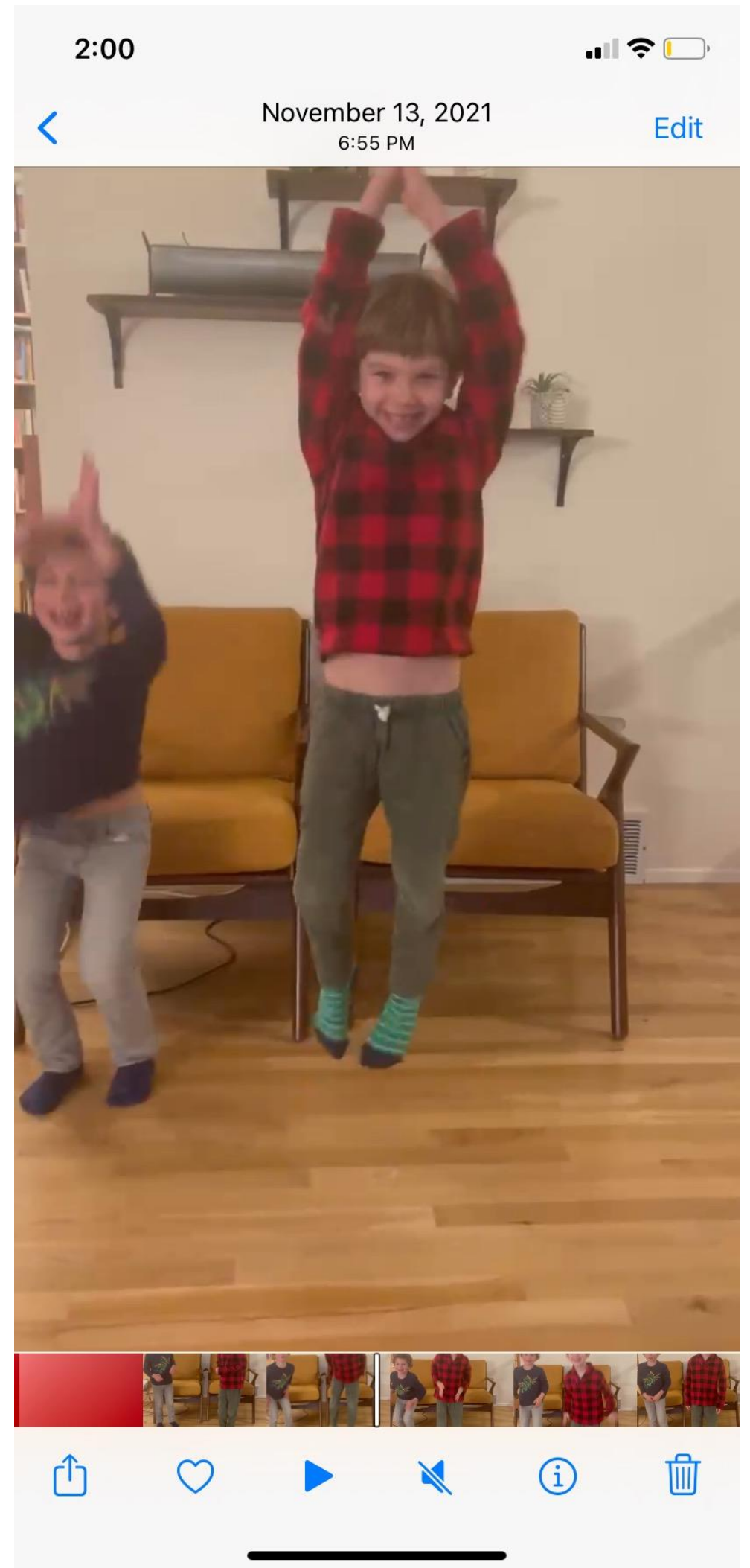

Figure 1: Two young children perform a fitness routine as their cousin records on a smartphone. Image provided by Debra Berliner. 
What kind of video is this? It is not purely what we have come to think of as the home movie, in which only "invested spectators"- those who care about the children involved in its production have a stake or interest in watching, preserving, or circulating the text. ${ }^{1}$ Viewers beyond the family saw it even before some of the children's parents. And despite its resemblance to online video memes (in both length and content), it is not exactly what is typically thought of as social media either, because it was circulated through direct, private messaging rather than through online social networks (such as Facebook or Instagram) or discovered by viewers through video search outcomes (as we would expect from video sharing platforms like YouTube or Vimeo). What, then, if it were to be posted on an online sharing platform and happened to go viral and earn profit for the person who posted it? The actual and potential lifecycle of this particular video points to a myriad of questions about for whom this video holds meaning. It matters who holds power over how that video might be appropriated, manipulated, monetised, or preserved. Its particular production and circulation path troubles existing categories of non-professional media, as does the content.

Archives of personal, family, or community media have always been rich and complex sites of analysis, albeit relatively closed ones. However, when we now upload personal media to video sharing platforms we subject them not only to new economies of scale, but of meaning and audience as well. ${ }^{2}$ One's personal media, once posted online, has the potential to reach millions of strangers, whose responses and interpretations will most certainly differ, reflecting new meaning back onto the text through comments and how, when, and to whom it is circulated. This is compounded by the fact that it is almost impossible to possess or destroy a home movie once it is uploaded to an online platform. Someone may choose to remove the video, but that does not protect against prior downloads or the likely possibility that the file will remain on the platform's server. 
It is in these ways that the video text and its interpretation become quite literally out of the hands of the makers and subjects. Is the category of the home movie even useful in discussing the production and circulation of digital self-made media?

The capacities and uses of digital recording technologies and online file sharing platforms have complicated the status of the category of home movies and necessitate a revision to the analytical frameworks that several scholars have offered in the past. We are therefore compelled to confront a lacuna in the field of Cinema and Media Studies, a gap in language and theory for media that troubles the line between familiar amateur or nonprofessional forms, and what is commonly considered to be social media production. This essay puts home movie scholarship from the field of Cinema and Media Studies into conversation with digital media studies to examine the cataclysmic encounter between personal and social media production, circulation, and archival practice, in order to explore what might be revealed about the machinations of capitalist and datalogical forces regarding what gets produced, what gets circulated, what gets preserved, and why.

While the ubiquity of mobile media has enabled self-produced videos to become a fixture of popular culture, the prolific use of platforms such as YouTube and TikTok now requires us to take stock of how systems of producing, organising, and circulating this media are impacted by corporate profit motives, backend functionalities of the sites, and the inherent social bias embedded in them due to their existence within technosocial artifacts of racial capitalism. ${ }^{3}$

This essay questions what is valuable from the study of home movies that might help us to elucidate changes in self-made media making, and where are we pushed to find new taxonomies for understanding contemporary practices and their import. 


\section{A Brief Overview of the (Fragile) Category of Home Movies}

Home movies have historically shared common characteristics and aesthetics over many decades, and across media technologies. The common home movie conventions have become recognisable - from the shaky handheld camera, lack of professional lighting or sound, and grainy or pixelated footage, film stock or tape quality ${ }^{4}$ to the tacit acknowledgement from the subject(s) that they are aware of the camera. ${ }^{5}$ The home movie look has been relentlessly reproduced because of its familiarity as a form. Its formal characteristics have even become shorthand in many narrative and documentary films and television shows to signify realism, historical evidence, nostalgia, or a behind-the-scenes vantage point. Several video editing software programs now include "home movie" filters to give footage the look of small gauge film stock. Home movie clips, even the apocryphal ones created for narrative fiction programs, provide an intimacy through suggested access to more private moments - a backstage or backstory for the characters. Filmmaker and scholar Michelle Citron suggests that home movies construct "necessary fictions" used to shape specific narratives, rather than serving simply as recorded evidence of the particular dynamics or details of a family's past. ${ }^{6}$ The common use of home movies as quotations in fictional and documentary texts therefore underscores the paradox of the home movie genre itself; while they are used by makers and audiences as a way of presumably indexing the real, home movies only deepen or complicate stories that are being told.

Home movies, as a category, have had a niche role in the last several decades of cinema and media scholarship. The widespread access to imaging technologies after World War II encouraged many scholars to begin to consider the home movie to be as worthy of study as broadcast or commercial media. ${ }^{7}$ Visual anthropologist Richard Chalfen's 1986 book Snapshot Versions of Life continues to provide a particularly useful framework for understanding the conventions and communicative 
purpose of homemade media, specifically, for its introduction of the concept of the home mode of media production. ${ }^{8}$ Beginning with the premise that the home is not just a geographic but a conceptual space that is continually remade and reaffirmed through symbolic mediation, Chalfen describes the ways in which home is imagined through homemade media production while distinguishing personal and private features of home mode communication from mass modes of communication.

The category of the home mode draws boundaries around an autonomous field of practice in which amateur representations of domestic life and other things known to the invested spectator are produced to be (re)viewed by those within a delimited sphere that excludes strangers and mass audiences. Chalfen argues that the home mode must be studied distinctly from the professional formal codes, commercial system of exchange, and public context of typical image production. He argues that home movies, like family photo albums and other cultural artifacts, are produced in the home mode and therefore possess clearly defined conventions for the types of images produced, the circumstances under which they are made, and the kind of people and events that can be represented. In this way, the home mode is a means to symbolically unite the community through a visual network of social relationships. Home mode artifacts hold an important cultural function in the retention of details of people, places and events.

In the pre-digital time of Chalfen's writing, he noted that home mode media had autobiographical functions - to represent the events of one's own life, and to observe one's image in action, as well as rites of passage and seeing one's place in relation to others in the family. These functions have been used by families as performances of membership, identity and lifestyle, and they have enabled individuals to produce and circulate their own images, measure them against other images, 
and negotiate their place in a mediated culture. ${ }^{9}$ As a result, and perhaps most vital to our definition of the home movie form for the purposes of this article, viewers who were not already connected to the diegetic world of the home movie were therefore less able to draw on its contextual, intertextual, and indexical references. The symbolic world at the time of Chalfen's writing of the late 1980s was a relatively closed one. In other words, if you did not know or care about anyone in a given home movie, you would be less likely to care or want to watch it. If you have ever been asked to sit through another family's home movies, you have likely already discovered the truth in the claim.

We can utilise the concept of the home mode to account for contemporary media making practices because it is not simply a technological device deployed in a private setting (the family) but an active mode of media production representing everyday life: "a liminal space in which practitioners may explore and negotiate the competing demands of their public, communal and private personal identities." 10 The home mode provides a flexible lens with which to examine home movie production practice across time and technologies, and is therefore useful to us in our studies of contemporary online digital media in both formal characteristics and semiotics. In addition to the continuing impact of the specificities of the media that is used for recording and playback, the home mode is shaped by technological and economic structures.

Invoking Chalfen's original description of the home mode, film scholar James Moran, who was writing in the context of analogue video of the 1990s, reminds us that rather than existing solely at the service of a nuclear family, the home mode works to construct an image of home as a "cognitive and affective foundation [for] situating ourselves in the world." ${ }^{11}$ It also temporally situates, family members as it serves as material evidence of generational continuity - of one's 
connections to others, groups, rituals, and traditions. The act of video recording itself becomes an active tie that binds. Moran argues that the home mode has become more elastic to accommodate the shifts in familial constitution and dynamics, while families have continued to use the home mode to articulate and make visible their relationship. ${ }^{12}$

Using the symbolic work of home movie texts, other cinema and media scholars and practitioners have provided ways to think of home movie production and preservation as a site of ideological (re)production. As Patricia Zimmerman argues in her ground-breaking 1995 book Reel Families, home movie making practices, and their resulting image memories, serve an ideological function beyond the family dynamic. Writing at a time when VHS recording technologies made home movie recording, transfer and duplication more widespread, her historical study of nonprofessional film from 1897 until the mid-1990s considers the ways in which amateur film is "not simply an inert designation of inferior film practice and ideology but rather is a historical process of social control over representation." ${ }^{\prime 13}$ Zimmerman observes that ideology flowed through the home movie maker, often a family patriarch, who had the resources to buy a camera and process films, frequently relying on instruction manuals that encouraged particular norms of representation. The home movie obscured class, as well as other kinds of social differences, while promoting the (white, middle-class) nuclear family as the place of leisure and the centre of all meaningful activity. In these ways, she argues, home movies encouraged a retreat from social and political participation as well as family truths. Personal archives of home movies, therefore, can be seen as potent sites of a localised struggle over meaning, which is one reason why utilising home movies in personal documentary and experimental films has been such a compelling technique. ${ }^{14}$ 
Just as home movies in the personal sphere, through their organisation and use, have been part of an exercise of power, home movies have also historically been used in the production of and resistance to state and imperial power. Scholars such as Veena Hariharron and Julia Nordegraaf and Elvira Louw have illustrated how colonial archives of movies of everyday life of white settlers and bureaucrats were used to exert power by fortifying the colonial logics of domination and subordination and colonial ways of seeing the colonised other. ${ }^{15}$ Just as many independent professional filmmakers have reworked their personal home movies to make interventions into family representation, many others have also used home movies to resist dominant state narratives. ${ }^{16}$ And, with the ubiquity of digital, online video, anyone with an internet connection, a smartphone camera, and the appropriate software can edit videos to remix their personal media collection with available professional media. As YouTube proliferates with fanvids and remixes, critiquing state power has become common social media fare. ${ }^{17}$

\section{Expanding the home mode; challenging the archive}

The audience for home movies prior to online video sharing platforms was typically limited to private viewings by technology, too, as sharing movies was not possible without duplicating the footage and securing technologies for playback. For these reasons, home movies were rarely seen by others outside of the family or community depicted. With the introduction of consumer video in the late 1970s, however, amateur recording and reproduction devices proliferated, making home movie production more portable, less expensive, and simpler to use, widening the scope of who and what could be recorded and shared. Even so, with rare exceptions, home movie circulation was still limited to existing personal networks. 
Recognising the value of home mode media as a site of communication and meaning-production, there have been efforts on the part of several institutions, scholars, and organisations to collect "orphan" and "found" films, discern their provenance, screen, and catalogue them, as well as to collect the home movies of marginalised makers and make them available to researchers, artists, historians, genealogists, and community residents. There is an existing foundation of resources and networks that have been active in finding, organising, screening, archiving, contextualising, and circulating analogue media that might have otherwise found itself in a landfill or passed from attic to yard sale and back again. ${ }^{18}$ This includes the work of the Center for Home Movies, which has long organised public and community-based screenings of personal and "found" home movies, Rick Prelinger's gargantuan efforts to upload and make available found, donated, and open-source audio-visual media files through Archive.org, the traveling Found Footage Film Festival, and the archives at the Smithsonian National Museum of African American History and Culture. Prominent among the many community history projects that exist is film scholar Jacqueline Stewart's South Side Home Movie Project (SSHMP) which was launched in 2005 as "an archival and research initiative to collect, preserve and exhibit amateur films from Chicago's South Side" to correct the "notable absence of home movies (especially from minorities) in the canon of film scholarship." ${ }^{\prime 19}$ Increased public availability of home movies provides access to individual and family self-representations; at the same time, it also makes possible the use of home movies as a vital access point for academic approaches that trace the home movie's journey from official history to the more variegated and multiple practices of individual and collective memory. ${ }^{20}$

As Jasmyn Castro argues in relation to the home movies of Black families and communities, while they were initially recorded for the intention of private viewing, they ultimately "operate outside of the representational norms of mainstream theatrical media and thereby [are] able to transcend 
its limitations." ${ }^{21}$ In doing so, they "redefine mis-and-underrepresented Black communities; they provide an intimate moving image record that complements and counters the often-negative imagery in the media" while providing a resource for "re-examining and understanding the African American experience." ${ }^{\prime 22}$ The home media archive therefore works in contradistinction to commercial film of the same era of their production, what Castro calls the "microhistories that challenge the parameters of broader histories and film canons." ${ }^{23}$ Yet, as much as home movies have the potential to present "plural pasts" that challenge dominant representations, Crystal MunHye Baik warns us not to see them solely as an "oppositional schematic of power," but rather as full of contradictions that reflect the complexity of everyday life, a place to "track the discursive tensions" that emerge from the pairing of the everyday with a yearning for visibility. ${ }^{24}$

Baik urges us to consider the ways in which archives of historical home movies - whether they are in a family attic or a museum - are always remediated, generating new inscriptions of meaning through the act of curatorial decisions. As Stewart explains of her work with the SSHMP, the act of constructing a catalogue requires the archivist to contend with "overwhelming detail." Specific taxonomies and metadata are most useful when the archivist has additional context through oral histories and active participation with those who have connections to the texts. ${ }^{25}$ In the archivist's struggle to organise and make these home movie collections legible to the public, we are reminded the extent to which the arrangement and categorisation of any given archive and its parent organisation shapes the meaning surrounding its artifacts. ${ }^{26}$

These scholars gesture here not just to the incredible labour of home movie archiving and the process of remediating, but also to the process of signification and resignification that occurs along the way. The meaning that is inscribed through the cataloguing, screening, and circulation of home 
movies, hits high velocity with file sharing technology. Recent online video sharing platforms such as YouTube, and other file sharing applications have catapulted home mode media originally produced in the domestic sphere into the public realm. As a result, a vast and expanding international archive of home movies has begun to further complicate boundaries of public and private while demanding attention to its ongoing significance across geographies, families, cultures, time, and technological platforms. ${ }^{27}$ There are the obvious transformations, such as the ubiquity of high-definition cameras, online digital storage, and the ability to instantly share media to an unlimited audience across tremendous distances, and these changes have certainly shaped what is produced and shared. But I seek to draw attention to the less visible machinations of online media platforms and the ways they disrupt the concept of the home mode. Wider circulation adds complexity to the increased intermingling of amateur and commercial production ${ }^{28}$ while it amplifies an already common "amateur vernacular." 29 A combination of regulatory, technological, monetary, and social forces have come to bear on content and circulation. In what follows I point to several important shifts, aiming to bring digital media research to bear on our discussion.

\section{Platforms as Archive and Curator}

Prior to the ubiquity of mobile media and file sharing platforms, most home movie collections had been stored, maintained, or discarded by someone with a close (typically familial) connection to the people depicted. Artifacts of the domestic sphere and community life that typically wound up as part of the detritus and heirlooms of estates, their full context was unlikely to be understood by outsiders well enough for archival or even screening purposes ${ }^{30}$ Even most of the home movies that found their way into museum or library archives had very few people involved interacting with them. Home movies were also, by-and-large, not monetised - with the notable exceptions of Kato-chan Ken-chan Gokigen TV in Japan (1986 debut), the long-running hit television program 
Frames Cinema Journal, Issue 19 (March 2022)

and franchise America's Funniest Home Videos (1989 debut), and other international spinoffs which solicited viewers to submit videotaped clips of home movies for possible broadcast and prize money.

I am using the term "archive" as a term for sites for file storage, organisation, and narrativisation as opposed to a "collection," which refers more to accumulation and private meaning to the collector, than use. ${ }^{31}$ Referring to online video sharing platforms as archives is a complicated issue, as online file sharing platforms to date have not defined themselves as such. If anything, the disappearance or difficulty of finding videos online is more of a defining feature than any kind of reliable preservation and organisation system. However, YouTube, TikTok, Instagram, and Facebook have become ad hoc and default archives for many home mode movies, as many people have posted there in order to share widely within and beyond their networks. In doing so, they have, perhaps inadvertently, submitted their content (and rights to it) to the platform, in perpetuity. Yet while many users rely on platforms to host their videos, the actualities of how, where, and when the content is viewed and circulated are in part impacted by the laws and regulations (in most cases, the lack of regulations) that govern the platforms.

Conversely, some individuals, organisations, and institutions may intentionally use these platforms as an archive for their media, without necessarily knowing (or understanding) the terms and conditions that will shape the video's half-life. In other words, while these platforms may appear to function as archives for long-term storage and access, the actual functionality and fickleness of the systems in play betrays that potential. If we do accept these platforms as de facto archives, we must ask: who or what, then, is the archon, organising and systematising the files? We know that what can be seen by an individual user at any given time is a product of what search terms they 
have used, along with the meta-data and algorithms that shape what is viewable to them. That is very different from a grandparent making decisions about whether to transfer and duplicate the family's VHS home movies for the family or a community collecting the home movies they have gathered from others to develop a local archive for future historiography and identity formation.

The organisational logic of contemporary user-produced file sharing platforms is structured around optimising reach, and ultimately profit. Meta-data (the information users enter about their videos, including hashtags) and algorithms (embedded formulas that determine which videos play when and for whom) structure the user experience. Home mode media, then, is subject to the logics of the platform to determine its audience, and in turn, the audience to determine its lifecycle. As a result, videos are distributed and decontextualised from the family or home mode context and recontextualised within streams of content chosen by the platform. For example, imagine a video of a person making a wedding toast. The toast was then posted on YouTube and watched by not only the attendees and people who could not make it to the event, but by others to whom the video was suggested when they typed in search terms that matched the keyword tags. Search words like "weddings" or "toasts;" might call up this specific video, but even some seemingly minute detail or subjective reading such as "bridesmaid in ugly dress" or "funny speeches." Even suggestions of broadcast clips such as "Wedding Toast - Saturday Night Live" or infotainment from topicrelated organisations such as the public speaking club Toastmasters offering "Toastmasters Wedding Toast Tips" might come up. Whatever meaning the invested spectators of the initial wedding event might attribute to the subsequent video is situated in intertextual flows of meaning, by the algorithms that guide associations between videos. While the complexity of search terms and results also impacts the archives of home movies in general, what I aim to draw attention to here is how results found through online for-profit video sharing platforms organise home movies 
Frames Cinema Journal, Issue 19 (March 2022)

according to monetary logics - what is most liked, shared, commented on and therefore, monetisable. Video content is bound up in advertising revenue, and the profit-oriented structures of the site. Viewers are directed towards content that has proven itself successful according to these governing principles.

\section{Platforms have Politics}

As scholars of media and technology such as Tarleton Gillespie, Sofia Ujuoma Noble and Ruha Benjamin have all argued, online platforms are not neutral. ${ }^{32}$ They have existing politics that determine development and coding systems and the ways they are taken up by users often reflects and reinscribes social biases. Moreover, depending on their governing and regulatory structures, such as what counts as "offensive" or the flagging or blocking of copyrighted content, media sharing platforms will impose particular norms upon the videos that they host. At this very basic level, the invisible structures on the platform are already shaping what we do and do not see of other users' videos. On YouTube, community (also read as corporate-mandated) guidelines are literally presented as "common sense principles." 33 It is assumed that users will have an intuitive sense of what to post or not to post. And yet, that videos that circulate do so is because of their successful harnessing of algorithms and manoeuvring within a (digital) attention economy rather than due to their inherent social value. Evaluative structures, such as the "likes", "hearts", and "shares" found on many platforms, are known to boost attention, and further ensure the spreadability of the video. ${ }^{34}$ Video recommendations on YouTube, much like the automatic replenishing of videos on TikTok, are based on browsing history and the keywords and metadata attached to videos one has watched previously. When we treat platforms as neutral systems, and as de facto video archives, we fail to see how our encounters with these systems are shaped by their systems at every level. 
Algorithms are designed to keep you watching. ${ }^{35}$ This is because a user's time online produces capital, for the person who posted, as well as for advertisers, and investors through digital labour that may be experienced by users as pleasure or even fandom. ${ }^{36}$ The social capital of "likes" and "shares" is rewarded with monetary capital to the content creator, which is tied up in profit generated by the platform through its corporate relationships, and increasingly, directly to content producers as they acquire "influencer" status (meaning that they have large followings to their social media accounts that they leverage to persuade people to buy or use products and services). ${ }^{37}$ Capital is produced even when online file sharing platforms are not the vehicles of circulation. The circulation of the video of the children playing discussed at the start of this article, sent via an enriched online messaging platform, is an example of this. Circulation of the video was fully reliant on the makers and viewers having access to the technologies, broadband infrastructure (WiFi with the necessary speed), and storage capacity to record and/or share the video. Each share represents an investment and reliance on those systems that, while not immediately recognisable as bound up in capital, are, in the truest global sense. If the video were to be uploaded online and circulated through a platform like YouTube or TikTok, it is possible that, depending on how it was tagged and thereby framed for the audience, it could be monetisable to the person who posted it. We know that the home mode has truly moved out of the domestic sphere when we consider that any one of the current or future recipients of the video could choose to post it online and, if it were to circulate widely, profit from it.

Home movie aesthetics and conventions, and what they signal, have played an important role in the success of YouTube, TikTok and other platforms that are used for sharing user-produced videos. With the advent of viral videos and subsequent monetisation, a market opened for home movie uploads, particularly ones that mimicked successful formulas that had been codified through 
America's Funniest Home Videos and its spinoffs years earlier. ${ }^{38} A F H V$ and its lookalikes first introduced the idea that home movies could be mass entertainment that could attract sponsors, while the prize categories on the program organised videos into tropes that possible contributors could select or perform content for. Online meme culture resembles this self-fulfilling cultural production; easily reproduceable, imitated, or parodied content begets more of the same, hence the relentlessness of participatory viral video trends, like families doing choreographed dances (such as the "Nobody Dance" challenge) or clips of couples pranking each other (\#couplecomedy). ${ }^{39}$

When the formula is subverted, as in the example of the video Shanika Bradshaw posted of her 103-year-old grandmother Madie Scott answering questions about what it was like to pick cotton in Georgia when she was a young girl (on TikTok as @ blackbeauty_3), there is promise that the platform may yield the kind of archive of oral history that might empower the descendants of African American sharecroppers and formerly enslaved people in ways that home movie archivists have sought to do. ${ }^{40}$ The conversation between granddaughter and grandmother possesses home mode characteristics - a nonprofessional recording device and an intimate conversation between the two in which Bradshaw sounds genuinely surprised at aspects of her grandmother's story, as a television plays loudly in the background. Yet at the same time, we see the home mode being redefined in the intentional editing down to soundbites for a wider audience, and the additional overlay of text "Me asking my grandma about picking cotton." What's more, there is description below the video that encapsulates the most shocking aspects of Scott's three-minute story: "Grandma picked cotton from 3am to 5pm every day. She was paid barely anything. Smh! \#storytime." There is communication happening within the family as Scott shares her story with her kin, but further, through Bradshaw's editing and posting choices, communication also takes place with an imagined audience. That audience was not only hailed when Bradshaw posted the 
video to TikTok, but when she added a Twitter hashtag to circulate it by way of an additional platform.

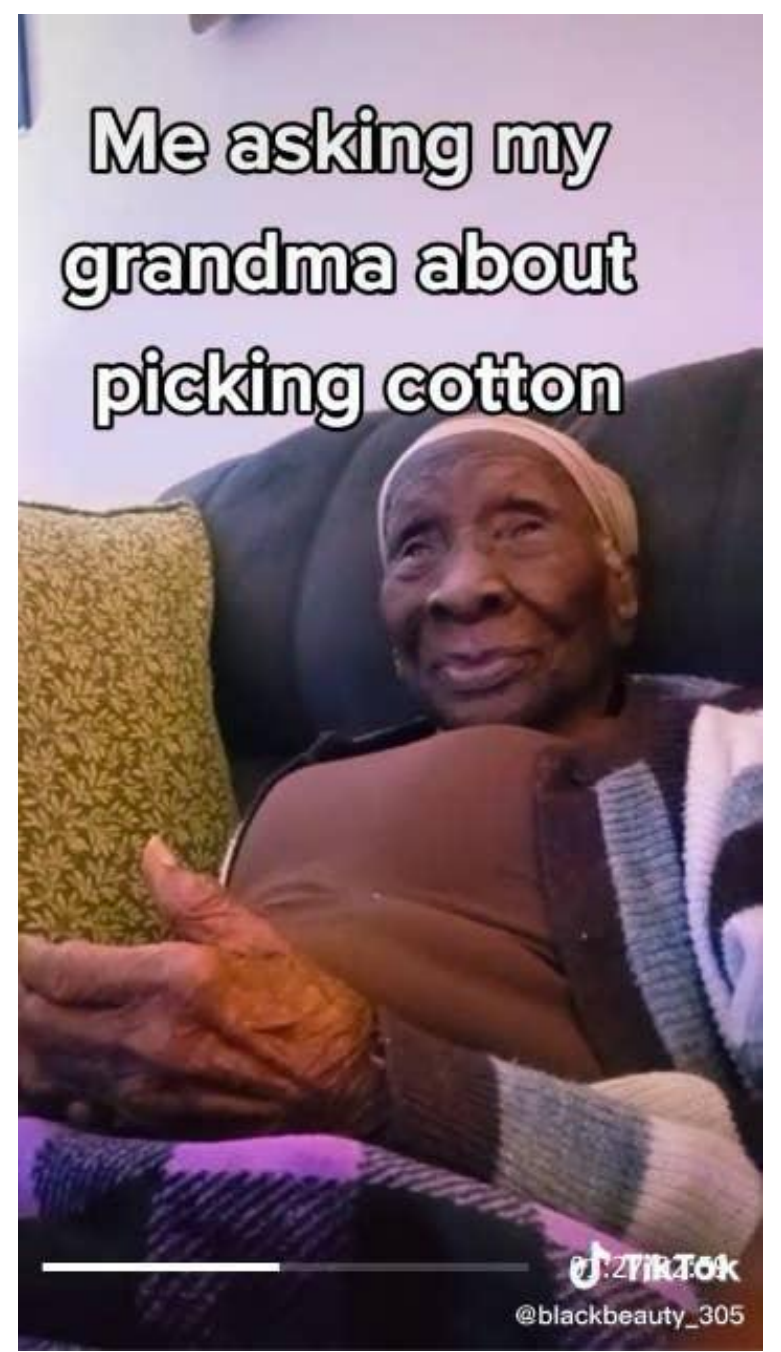

Figure 2: TikTok video still of 103 year-old Madie Scott, explaining to her granddaughter what it was like to pick cotton as a young girl in Georgia. Still image from the video by @blackbeauty_3 on TikTok.

The media buzz inspired by the virality of Bradshaw's video suggests its reach and impact. However, on the platform itself, there is no "outside" of existing profit structures. While Bradshaw and her grandmother may ultimately get paid for the views of the video, the platform profits from its circulation. The media outlets that have publicised the human interest and historical value of the video also profit from this content, such as People Magazine, the NY Post, and The 
Independent. What comments will appear, who shares the video, and with what framing is beyond Bradshaw (and certainly her grandmother's) control. In this way, the platform acts as archon, constantly re-contextualising the video in new ways to new people in response to user clicks, comments, and shares.

While the video depicts Scott telling an important part of her history, and the history of racial injustice in the United States more generally, Bradshaw's lack of control over the interpretation, framing, circulation, and use of the video once it is circulating through the platform, is potentially troubling. Ruha Benjamin warns that the tenets of racial capitalism are encoded into media technologies like TikTok, as the technosocial structures that undergird online video file sharing platforms work to reproduce existing biases. ${ }^{41}$ She writes of what she pointedly identifies as a "New Jim Code," in which recent technologies invoke discriminatory practices of previous eras while claiming to be more objective or progressive. It is the perceived neutrality of these technologies that is dangerous, for they continue to do the work of reproducing inequality and racist ideologies, further obscuring how Black people's labour and bodies continue to produce capital for white entities. Sheldon Pearse has written about how despite the diversity of TikTok content producers, the most visible and most followed TikTok trends feature white stars, often "feed[ing] off of the content of smaller users in an act of vampirism, growing stronger as competitors wither away, using culture as a commodity to maintain their positions." Black cultural production is thereby credited to white producers. And as Safiya Noble underscores in Algorithms of Oppression, the pornographic and anti-Black results that appear when conducting a Google search for "Black girls" emerges from either "corporate logic of either wilful neglect or a profit motive that makes money from racism and sexism." ${ }^{42}$ It is of critical importance for scholars in the field to identify, analyse, and help undo the white supremacist architectures of the platforms 
Frames Cinema Journal, Issue 19 (March 2022)

we examine. Even though online video file-sharing platforms may appear to enhance the visibility of people at the margins, we must look to the structures that condition, and profit from, their participation.

\section{Conclusion}

Online practices of self-representation challenge earlier frameworks of "amateur" and "nonprofessional" media production by opening up onto different kinds of capitalist relations as they expand on existing notions of how we think about "home" and other personal/domestic spheres. As we consider the status of home movies in the online digital landscape, it is important to consider the ways home mode communication is no longer simply adjacent to commercial media practices, but rather, part of a diverse, self-made media production ecology that is contiguous with other commercial and profit-oriented media practices. The home mode of making, as we have understood it as a field, has been replaced by personal media that has been sculpted by makers and algorithms to deliver clicks, likes, shares, and ultimately, profit. The representation of the personal sphere, performance for a possibly unknown audience, and the overlapping of circuits of meaning that are inscribed and reinscribed through online video-circulation puts pressure on existing taxonomies and frameworks.

Online video platforms and the media they store and circulate now structure meaning and reinscribe relationships of power within and among home mode representations while pushing us to attend to the curatorial power of the systems and entities that shape what circulates, how it does, and why. Of importance is attention to how capital flows through these systems, commodifying images, affect, gestures, expression, movement, sounds, and desire, and how and where existing social biases are reproduced or challenged. 


\section{Notes}

${ }^{1}$ Richard Chalfen, Snapshot Versions of Life (Bowling Green, OH: Bowling Green University Popular Press, 1987), 11.

2 José Van Dijck, Mediated Memories: Personal Cultural Memory in the Digital Age (Stanford, CA: Stanford University Press, 2007).

${ }^{3}$ Ruha Benjamin, Race After Technology: Abolitionist Tools for the New Jim Crow (Cambridge, UK: Polity Press, 2019).

${ }^{4}$ Vivian Sobchack. "'Me, Myself, and I': On the Uncanny in Home Movies" in The Structures of the Film Experience by Jean-Pierre Meunier: Historical Assessments and Phenomenological Expansions, eds. Julian Hanich and Daniel Fairfax (Amsterdam: Amsterdam University Press, 2019), 205-217.

${ }^{5}$ Liz Czach,"Acting and Performance in Home Movies and Amateur Films" in Theorizing Film Acting, ed. Aaron Taylor, (Routledge, 2012), 160-174.

${ }^{6}$ Michelle Citron, Home Movies and Other Necessary Fictions, (Minneapolis: University of Minnesota Press, 1999).

${ }^{7}$ Erens, Patricia, ed. "The Galler Home Movies: A Case Study." In The Journal of Film and Video 38 (nos. 3-4 summer-fall 1986: 15-24), 4.

${ }^{8}$ In his study, Chalfen analysed home movies shot between 1940-1980 by approximately 200 (mostly white upper-middle class) families living in the north-eastern United States, in conjunction with the data from survey questionnaires and interviews collected from the participants. The study is a content analysis of the people who appear in the images and aims to resolve how real-life and symbolic pictorial communities are related to each other, and how on-going human life has been transformed into symbolic representation. Through ethnographic analysis, Chalfen endeavores to resituate the historical importance of the forgotten archives of amateur images. He argues that these images could bring into focus other hidden dimensions of social and cultural significance and work toward (re)interpreting twentieth-century ideals, while providing inroads toward the production and circulation of histories that can challenge those promulgated by (professionally produced) Hollywood cinema and network television

${ }^{9}$ Chalfen, 10 .

${ }^{10}$ James Moran, There's No Place Like Home Video (Minneapolis, MN: University of Minnesota Press, 2002), 132.

${ }^{11}$ Chalfen, 61

${ }^{12}$ Moran argues that scholars must extend the notion of the home mode "to household, to place of residence, or to a place of origin." The home mode is "an ideal envisioned as the synthesis of three experimental domains: a personal, private space for memory or solitude; a social, public space for family or group interaction; and a physical space designed for comfort or security." It is in this expansion of the conception of the home mode that videos of events like protest marches and Pride parades can fit; they are events in which values, traditions and symbols of groups are transmitted and maintained. Moran, 61.

${ }^{13}$ Patricia R. Zimmerman. Reel Families: A Social History of Amateur Film. (Bloomington, IN: Indiana University Press, 1995), xv

${ }^{14}$ In tandem with home movie scholarship, many filmmakers have appropriated their own family home movies to destabilise and redress representation in the texts, utilising the home mode as a fluid substrate with which to rewrite personal and family histories. Su Friedrich's Sink or Swim (1990, 16mm, b\&w, 48 m), Michelle Citron's Daughter Rite, Peggy Ahwesh's From Romance to Ritual (1985) and The Vision Machine (1997), Andrew Jarecki's Capturing the Friedmans (2003), and Jonathan Caouette's Tarnation (2003).

${ }^{15}$ Veena Hariharan. "At Home in the Empire: Reading Colonial Home Movies-The Hyde Collection (1928-1937).” BioScope: South Asian Screen Studies 5, no. 1 (January 2014): 49-61; Julia Noordegraaf 
and Elvira Louw, "Extended Family Films: Home Movies in the State-Sponsored Archive." Moving Image 9, no. 1 (2009), 98;

Crystal Mun-Hye Baik, "The Right Kind of Family: Memories to Light and the Home Movie as Racialized Technology" in Screening Race in Nontheatrical film, eds, Marsha Gordon and Allyson Nadia Field, (Durham, NC: Duke University Press, 2019).

${ }^{16}$ Karen L. Ishizuka and Broderik Fox have emphasised how resistant ways of seeing are made possible through filmic depictions of the subaltern, highlighting the work that movies made by incarcerated Japanese Americans during World War II that provide first-hand accounts of subjugation and the experience of internment. Karen L. Ishizuka and Patricia Zimmerman's edited collection Mining the Home Movie brings these seemingly contradictory sites of nonprofessional production to the fore to recognize an historical method that finds evidence and draws interpretations of history from the disjunctures and contradictions of plural pasts, while also presenting a quarry of audio-visual details from which to extract information for future inquiry. Karen L. Ishizuka and Patricia R. Zimmerman, Patricia R. Mining the Home Movie: Excavations in Histories and Memories (Berkeley and Los Angeles, CA: University of California Press, 2008); Broderik Fox, "Home Movies and Historiography: Amateur Film's Re-Vision of Japanese-American Internment," Spectator 26:2 (Fall 2006): 9-21.

${ }^{17}$ E. Charlotte Stevens defines fanvid as "derived from television and film sources, and approximate commercial music videos in form and duration, but are non-commercial fan works which construct creative and critical analyses of existing media. Vids are currently made and distributed digitally; however, the practice itself predates fandom's move online. Structurally, a vid is a montage of extracts from media in a personal archive. E. Charlotte Stevens. "On Vidding: The Home Media Archive and Vernacular Historiography" in Cult Media: Re-Packaged, Re-released and Restored, edited by Jonathan Wroot, and Andy Willis (Springer International Publishing, 2017).

${ }^{18}$ Center for Home Movies, https://www.centerforhomemovies.org; Prelinger Archive, https://archive.org/details/prelinger; Found Footage festival, http://www.foundfootagefest.com/, Smithsonian National Museum of African American History and Culture, https://www.si.edu/museums/african-american-museum, The South Side Home Movie Project, Center for the Study of Race, Politics and Culture https://csrpc.uchicago.edu/programs/projects/sshmp/

${ }^{19}$ The South Side Home Movie Project, Center for the Study of Race, Politics and Culture https://csrpc.uchicago.edu/programs/projects/sshmp/

${ }^{20}$ Karen L. Ishizuka and Patricia R. Zimmerman, Patricia R. Mining the Home Movie: Excavations in Histories and Memories (Berkeley and Los Angeles, CA: University of California Press, 2008).

${ }^{21}$ Jasmyn R. Castro, "Black Home Movies: Time to Represent" in Screening Race in Nontheatrical film, eds, Marsha Gordon and Allyson Nadia Field, (Durham, NC: Duke University Press, 2019).

${ }^{22}$ Castro, 373

${ }^{23}$ Castro, 373

${ }^{24}$ Baik, 357

${ }^{25}$ Jacqueline Najuma Stewart. "Giving Voice, Taking Voice: Nonwhite and Theatrical” in Screening Race in Nontheatrical film, eds, Marsha Gordon and Allyson Nadia Field, (Durham, NC: Duke University Press, 2019), xix

${ }^{26}$ Here I am drawing on the work of Allan Sekula's seminal essay "The Body and the Archive," in which he illustrated how the filing cabinet where mugshots were stored actually produced "the criminal" through their organization and use. For Sekula, the apparatus surrounding the visual is what held the meaning even more than the particular images it contained. Sekula, Alan. "The Body and the Archive," October, (1986) 39, 3-68.

${ }^{27}$ In 2010, the Center for Home Movies held a Digitization and Access Summit at the United States Library of Congress. As the CHM website states, "the Summit participants addressed the technical and legal issues surrounding the digitization of amateur film and video, the role of cataloging and description, and the impact that significantly increased online access to home movies would have on home movie makers, families, researchers, documentary filmmakers and the public." https://www.centerforhomemovies.org/homemoviesummit.html 
${ }^{28}$ For more on the relationship between home movies and television production, see John Thornton Caldwell's book Televisuality: Style Crisis and Authority in American Television (New Brunswick, NJ: Rutgers University Press, 1995).

${ }^{29} \mathrm{I}$ am drawing on Hetrick, who, referring to amateur video practice, uses the term video vernacular as "a new and more precise category to describe nonfiction videos made by untrained camera operators who attempt to realistically reflect life around them. Patricia Aufderheide also uses this term in the 1995 edition of Columbia Journalism Review (33, no. 5).

${ }^{30}$ Dwight Swanson. "The Tantalizing Challenges of the Home Movie Archive," Velvet Light Trap; Austin Iss. 70, (Fall 2012): 59-60.

${ }^{31}$ E. Charlotte Stevens. "On Vidding: The Home Media Archive and Vernacular Historiography” in Cult Media: Re-Packaged, Re-released and Restored, edited by Jonathan Wroot, and Andy Willis, Springer International Publishing, 2017, 148.

32 Tarleton Gillespie, "The Politics of 'Platforms'" New media \& society 12, no. 3 (2010): 347-364, Safiya Umoja Noble, Algorithms of Oppression: How Search Engines Reinforce Racism (New York: NYU Press, 2018), Ruha Benjamin, Race After Technology: Abolitionist Tools for the New Jim Crow (Cambridge, UK, Polity Press, 2019).

${ }^{33}$ Berliner, Lauren S. "Shooting for Profit: The Monetary Logic of the YouTube Home Movie" in Amateur Filmmaking: The Home Movie, the Archive, the Web, ed. Laura Rascaroli, Gwenda Young and Barry Monahan. Bloomsbury Academic, 2013, 289-300.

${ }^{34}$ Henry Jenkins, Sam Ford and Joshua Green. Spreadable Media (New York, NY: NYU Press, 2013).

35 Jia Tolentino, "How Tik Tok Holds our Attention," The New Yorker, September 23, 2019

${ }^{36}$ Mark Andrejevic. "Estranged free labor." In Digital labor: The Internet as Playground and Factory, ed Trebor Scholz (Routledge, 2012), 157-172.

37 "Are Social Media Influencers Worth the Investment"? https://www.forbes.com/sites/forbesagencycouncil/2018/08/21/are-social-media-influencers-worth-theinvestment/?sh=1ff82e $32 \mathrm{f} 452$

${ }_{38}^{38}$ Berliner, 289-300.

${ }^{39}$ \#nobodydancevideo, https://www.tiktok.com/tag/nobodydancevideo?referer_url=https\%3A\%2F\%2Fwww.mabelandmoxie.co m\%2F\&referer_video_id=6807326063543274758\&refer=embed, accessed December 1, 2021.

"\#couplecomedy,"

https://www.tiktok.com/tag/couplecomedy?referer_url=https\%3A\%2F\%2Fwww.cosmopolitan.com\%2F \&referer video $\mathrm{id}=6808982629845634309 \&$ refer=embed\&is copy url=1\&is from webapp $=\mathrm{v} 1$, accessed December 1, 2021.

${ }^{40}$ https://www.tiktok.com/@blackbeauty 305?referer url=https\%3A\%2F\%2Fwww.blackenterprise.com \%2F\&referer video id=7029850485989379333\&refer=embed

${ }^{41}$ Ruha Benjamin, Race After Technology: Abolitionist Tools for the New Jim Crow (Cambridge, UK: Polity Press, 2019).

${ }^{42}$ Safiya Umoja Noble, Algorithms of Oppression: How Search Engines Reinforce Racism (New York, NY: NYU Press, 2018).

\section{Bibliography}

Mark Andrejevic. "Estranged free labor." In Digital labor: The Internet as Playground and Factory, ed. Trebor Scholz (Routledge, 2012), 157-172. 
Patricia Aufderheide, "Vernacular video." Columbia Journalism Review 33, no. 5 (1995): 46.

Crystal Mun-Hye Baik, "The Right Kind of Family: Memories to Light and the Home Movie as Racialized Technology" in Screening Race in Nontheatrical film, eds, Marsha Gordon and Allyson Nadia Field, (Durham, NC: Duke University Press, 2019).

Berliner, Lauren S. "Shooting for Profit: The Monetary Logic of the YouTube Home Movie" in Amateur Filmmaking: The Home Movie, the Archive, the Web, ed. Laura Rascaroli, Gwenda Young and Barry Monahan. Bloomsbury Academic, 2013, 289-300.

Ruha Benjamin, Race After Technology: Abolitionist Tools for the New Jim Crow (Cambridge, UK: Polity Press, 2019).

Susan Blackmore, The Meme Machine, (New York, NY: Oxford University Press, 1999);

Jasmyn R. Castro, "Black Home Movies: Time to Represent" in Screening Race in Nontheatrical film, eds, Marsha Gordon and Allyson Nadia Field, (Durham, NC: Duke University Press, 2019)

Chalfen, Richard. Snapshot Versions of Life. Bowling Green, OH: Bowling Green University Popular Press, 1987.

Citron, Michelle. Home Movies and Other Necessary Fictions. Minneapolis, MN: University of Minnesota Press, 1999.

Czach, Liz. "Acting and Performance in Home Movies and Amateur Films" in Theorizing Film Acting, ed. Aaron Taylor, Routledge, 2012, 160-174.

Erens, Patricia ed. "The Galler Home Movies: A Case Study." In The Journal of Film and Video 38, nos. 3-4 (Summer-Fall 1986): 15-24, 4. 
Frames Cinema Journal, Issue 19 (March 2022)

Fox, Broderik. "Home Movies and Historiography: Amateur Film's Re-Vision of JapaneseAmerican Internment,” Spectator 26:2 (Fall 2006): 9-21.

Gillespie, Tarleton. "The Politics of 'Platforms'.” New media \& society 12, no. 3 (2010): 347364.

Gordon, Marsha and Allyson Nadia Field. Screening Race in Nontheatrical Film. Durham, NC: Duke University Press, 2019.

Gehl, Robert "YouTube as Archive: Who Will Curate This Digital Wunderkammer?” International Journal of Cultural Studies 12, no. 1 (January 2009): 4360

Hariharan, Veena. "At Home in the Empire: Reading Colonial Home Movies-The Hyde Collection (1928-1937).” BioScope: South Asian Screen Studies 5, no. 1 (January 2014): $49-61$.

Hetrick, Judi. "Amateur Video Must Not be Overlooked” in The Moving Image 6.1 (2006) 6681

Ishizuka, Karen L. and Patricia R. Zimmerman, Patricia R. Mining the Home Movie: Excavations in Histories and Memories. Berkeley and Los Angeles, CA: University of California Press, 2008.

Jenkins, Henry, Sam Ford and Joshua Green. Spreadable Media. New York, NY: NYU Press, 2013.

Moran, James. There's No Place Like Home Video. Minneapolis, MN: University of Minnesota Press, 2002.

Noble, Safiya Umoja. Algorithms of Oppression: How Search Engines Reinforce Racism. New York, NY: NYU Press, 2018. 
Noordegraaf, Julia and Elvira Louw, "Extended Family Films: Home Movies in the StateSponsored Archive." Moving Image 9, no. 1 (2009): 98.

Pearse, Sheldon. "The Whitewashing of Black Music on TikTok," The New Yorker, September 9, 2020.

Rascaroli, Laura, Gwenda Young, and Barry Monahan. Amateur Filmmaking: The Home Movie, The Archive, The Web. Bloomsbury, 2014.

Sekula, Alan. "The Body and the Archive," October, (1986) 39, 3-68.

Shifman, Limor, Memes in Digital Culture. Cambridge, MA: MIT Press, 2014.

Sobchack, Vivian. "'Me, Myself, and I': On the Uncanny in Home Movies" in The Structures of the Film Experience by Jean-Pierre Meunier: Historical Assessments and Phenomenological Expansions, eds. Julian Hanich and Daniel Fairfax (Amsterdam: Amsterdam University Press, 2019), 205-217.

Stewart, Jacqueline Najuma. "Giving Voice, Taking Voice: Nonwhite and Theatrical" in Screening Race in Nontheatrical film, eds, Marsha Gordon and Allyson Nadia Field. Durham, NC: Duke University Press, 2019.

The South Side Home Movie Project, https://csrpc.uchicago.edu/programs/projects/sshmp/

Stevens, E. Charlotte. "On Vidding: The Home Media Archive and Vernacular Historiography" in Cult Media: Re-Packaged, Re-released and Restored, edited by Jonathan Wroot, and Andy Willis. Springer International Publishing, 2017.

Swanson, Dwight. "The Tantalizing Challenges of the Home Movie Archive," Velvet Light Trap; Austin Iss. 70, (Fall 2012): 59-60.

Tolentino, Jia, "How Tik Tok Holds our Attention,” The New Yorker, September 23, 2019. 
Van Dijck, José, Mediated Memories: Personal Cultural Memory in the Digital Age. Stanford, CA: Stanford University Press, 2007.

Wasson, Haidee. Everyday Movies: Portable Film Projectors and the Transformation of American Culture. Oakland, CA: University of California Press, 2020.

Zimmerman, Patricia R. Reel Families: A Social History of Amateur Film. Bloomington, IN: Indiana University Press, 1995.

\section{Author Biography}

Lauren S. Berliner is Associate Professor of Media \& Communication Studies and Cultural Studies at University of Washington Bothell where she teaches courses in digital media studies and visual culture. She is the author of the book Producing Queer Youth: the Paradox of Digital Media Empowerment and co-editor of Feminist Interventions in Participatory Media: Pedagogy, Publics, Practice. Her writing has also appeared in JCMS, The Cine-files, several edited book collections, and can be seen in a forthcoming issue of Feminist Media Histories (Spring 2022) She is also an Associate Director of The Festival of (In)Appropriation, an annual showcase of experimental media. 